\title{
Characterization of Tamarind Accessions for Morphometric Traits and Phytochemical Composition
}

\author{
R. Praveenakumar ${ }^{1 *}$, G. Gopinath ${ }^{1}$, S. Shyamalamma ${ }^{2}$, S. Ramesh $^{3}$, \\ M. Vasundhara ${ }^{1}$ and M. Chandre Gowda ${ }^{1}$ \\ ${ }^{1}$ Department of Horticulture, ${ }^{3}$ Department of Genetics and Plant Breeding, University of \\ Agricultural Sciences, GKVK, Bangalore, India \\ ${ }^{2}$ Post Graduate Institute of Post Harvest Management, Dr. Balasaheb Sawant Konkan Krishi \\ Vidyapeeth, Killa-Roha, Raigad-402 116, Maharashtra, India \\ *Corresponding author
}

\section{A B S T R A C T}

\section{Keywords}

Characterization,

Tamarind,

Accessions,

Morphometric and

phytochemical

Article Info

Accepted:

10 September 2020

Available Online:

10 October 2020

\begin{abstract}
The present study on "Characterization of tamarind accessions for morphometric traits and phytochemical composition" was carried out at Department of Horticulture, College of Agriculture, UAS, GKVK, Bangalore, during 2018-19 and 2019-20. The experiment was laid out in a Randomized Block Design with three replications and twenty two accessions with the objective to find out the superior fruit characters and phytochemical parameters genotypes. Significant variations were observed among the genotypes with respect to fruit characters and quality parameters. Among all the genotypes studied higher morphometric traits and quality traits were obtained in accession GKTAM-18 showing maximum pod weight $(35.61 \mathrm{~g})$, pod length $(19.85 \mathrm{~cm})$, pod width $(3.60 \mathrm{~cm})$, pulp weight $(18.94 \mathrm{~g})$, shell weight $(8.73 \mathrm{~g})$, seed per cent $(28.99 \%)$, fiber per cent $(6.65 \%)$ and acidity per cent (18.94\%). Maximum pulp per cent $(55.79 \%)$ was recorded in GKTAM -1, whereas higher TSS $\left(21.37^{\circ}\right.$ Brix) was observed in GKTAM -16. On the basis of the present study, GKTAM-18 showed the highest mean performance for morphometric traits and phytochemical characters and it can be utilized for further evaluation programme.
\end{abstract}

\section{Introduction}

Tamarind (Tamarindus indica L.) is a hardy evergreen monotypic tree which belongs to the family 'Leguminosae' and sub-family Caesalpinaceae and with chromosome number $2 n=24$. The name tamarind was derived from the Arabic word 'Tamar-EHind' meaning 'Date of India'. It is cultivated throughout the tropics and sub-tropics of the world and has become naturalized at many places. Tamarind is an economically important tree of India as well as Karnataka. In India, it is abundantly grown in Madhya Pradesh, Bihar, Andhra Pradesh and Tamil Nadu (El- Siddig et al., 2006).

There is a considerable genetic variation exists in tamarind with regard to quantitative character as well as traits contributing to quality of fruits like fruit weight, fruit length, fruit width, fruit thickness, number of seeds, pulp weight, shell weight and seed weight per fruit. 
Characterization for morphometric traits and phytochemical traits of any genotypes, it is necessary to give attention to all the yield contributing characters. Under such circumstances knowledge of interrelationship among different traits is also necessary. It is essential to access the degree of association of various quantitative characters in order to initiate effective selection programme. The present study was, therefore, aimed to characterization of tamarind accessions for morphometric traits and phytochemical composition.

\section{Materials and Methods}

The present investigation entitled "Characterization of tamarind accessions for morphometric traits and phytochemical composition" was carried out during 2018-19 and 2019-20 at Department of Horticulture, college of Agriculture, UAS, GKVK, Bangalore. The experiment was laid out in a randomized block design with three replications and 22 genotypes viz., GKTAM1, GKTAM-2, GKTAM-3, GKTAM-4, GKTAM-5, GKTAM-6, GKTAM-7, GKTAM-8, GKTAM-9, GKTAM-10, GKTAM-11, GKTAM-12, GKTAM-13, GKTAM-14, GKTAM-15, GKTAM-16, GKTAM-17, GKTAM-18, GKTAM-19, GKTAM-20, GKTAM-21 and GKTAM-22. The observations for thirteen quantitative characters (pod length, pod width, pod thickness, pod weight, seed weight per pod, pulp weight per pod, vein weight per pod, shell weight per pod, number of seeds per pod and per cent of pulp, seed, shell, and vein) were recorded for all the genotypes selected for study. A total of 30 pods, 8 in each replication were collected and average was computed for the pod characters studied. The methods used for the estimation of various quality parameters of tamarind are recorded as per Ranganna (1979) are mentioned below. Total soluble solids of tamarind pulp was recorded by using an ERMA Hand Refractometer (0-32 ${ }^{\circ}$ Brix) and it was expressed as ${ }^{\circ}$ Brix. The $\mathrm{pH}$ of the pulp was determined by using a digital $\mathrm{u}-365 \mathrm{pH}$ meter.

\section{Results and Discussion}

Variability exhibited for fruit weight, fruit length, fruit width, seed weight per pod and pulp weight per pod by different tamarind genotypes are described in (Table 1). The findings revealed that among 22 genotypes evaluated, GKTAM -18 genotype recorded the highest values in all the yield characters. In the present study pod characters such as pod weight $(\mathrm{g})$, pod length $(\mathrm{cm})$, pod width $(\mathrm{cm})$, seed weight per pod $(\mathrm{g})$ and pulp weight per pod (g) are presented in Table 1. Regarding pod weight, accession GKTAM 18 recorded the highest weight of $35.61 \mathrm{~g}$ followed by GKTAM -1 (33.27 g). The lowest pod weight was observed in GKTAM $20(18.89 \mathrm{~g})$. in the case of pod length GKTAM -18 recorded the maximum length $(19.85 \mathrm{~cm})$ followed by gkvk-7 $(17.84 \mathrm{~cm})$. The lower pod length was observed in GKTAM-10 (12.12 cm). Pod width GKTAM -18 recorded the higher value of $3.60 \mathrm{~cm}$ and the lowest was noticed in GKTAM -10 (12.12 $\mathrm{cm})$. The same trend was observed in seed weight per pod $(\mathrm{g})$ also.

The higher value was found in GKTAM$18(8.35 \mathrm{~g})$ but lower seed weight per pod was observed in GKTAM-22 (5.03 g). Higher pulp weight per pod was recorded in GKTAM-18 (18.94 g). The lowest pulp weight per pod was observed in GKTAM-21 $(9.10 \mathrm{~g})$. This might be due the genetic characters of genotypes.

The difference in pod weight, pod width, and pulp weight per fruit was attributed to the variation in size and shape of the pod and also effect of genotypic differences among the genotypes. The observations regarding fruit 
width and pulp weight was earlier reported by Divakara (2008), Rao and Subramanyam (2010) and Fandohan et al., (2011).

Variability exhibited for Shell weight per fruit, Pulp per cent, shell per cent, seed per cent and fiber per cent by different tamarind genotypes are described in (Table 2). In the present study fruit characters were significantly difference among the 22 tamarind genotypes evaluated. The highest shell weight recorded in GKTAM-18 genotype $(8.73 \mathrm{~g})$ which was higher than among the 22 genotypes evaluated followed by GKTAM-1(6.80 g). The lowest shell weight was found in GKTAM -17 of $3.89 \mathrm{~g}$. The highest pulp per cent was recorded in GKTAM-1 of 55.79 per cent, followed by GKTAM-18 (53.24\%).

Table.1 Variability exhibited for fruit weight, fruit length, fruit width, seed weight per pod and pulp weight per pod by different tamarind genotypes

\begin{tabular}{|c|c|c|c|c|c|c|c|}
\hline Treatments & \multicolumn{2}{|c|}{ Genotypes } & $\begin{array}{c}\text { Pod } \\
\text { weight (g) }\end{array}$ & $\begin{array}{l}\text { Pod } \\
\text { length } \\
(\mathrm{cm})\end{array}$ & $\begin{array}{c}\text { Pod } \\
\text { width } \\
(\mathrm{cm})\end{array}$ & $\begin{array}{l}\text { Seed weight } \\
\text { per pod (g) }\end{array}$ & $\begin{array}{l}\text { Pulp weight } \\
\text { per pod (g) }\end{array}$ \\
\hline $\mathbf{T}_{1}$ & \multicolumn{2}{|c|}{ GKTAM-1 } & 33.27 & 17.55 & 3.24 & 8.35 & 18.56 \\
\hline $\mathbf{T}_{2}$ & \multicolumn{2}{|c|}{ GKTAM-2 } & 27.46 & 15.20 & 2.47 & 6.68 & 13.50 \\
\hline $\mathbf{T}_{\mathbf{3}}$ & \multicolumn{2}{|c|}{ GKTAM-3 } & 27.51 & 16.39 & 2.53 & 6.35 & 13.29 \\
\hline $\mathbf{T}_{4}$ & \multicolumn{2}{|c|}{ GKTAM-4 } & 24.94 & 15.48 & 2.58 & 5.76 & 11.79 \\
\hline $\mathbf{T}_{5}$ & \multicolumn{2}{|c|}{ GKTAM-5 } & 26.61 & 15.79 & 2.37 & 5.93 & 12.69 \\
\hline $\mathbf{T}_{6}$ & \multicolumn{2}{|c|}{ GKTAM-6 } & 21.29 & 14.81 & 2.50 & 5.61 & 11.20 \\
\hline $\mathbf{T}_{7}$ & \multicolumn{2}{|c|}{ GKTAM-7 } & 26.13 & 15.74 & 2.37 & 6.45 & 11.39 \\
\hline $\mathbf{T}_{8}$ & \multicolumn{2}{|c|}{ GKTAM-8 } & 20.41 & 15.35 & 2.38 & 5.49 & 10.05 \\
\hline $\mathbf{T}_{9}$ & \multicolumn{2}{|c|}{ GKTAM-9 } & 27.94 & 15.47 & 2.41 & 7.46 & 12.40 \\
\hline $\mathbf{T}_{10}$ & \multicolumn{2}{|c|}{ GKTAM-10 } & 22.75 & 12.12 & 2.18 & 5.88 & 10.77 \\
\hline $\mathbf{T}_{11}$ & \multicolumn{2}{|c|}{ GKTAM-11 } & 20.84 & 14.06 & 2.45 & 5.73 & 10.48 \\
\hline $\mathbf{T}_{12}$ & \multicolumn{2}{|c|}{ GKTAM-12 } & 24.35 & 17.53 & 2.49 & 6.61 & 10.53 \\
\hline $\mathbf{T}_{13}$ & \multicolumn{2}{|c|}{ GKTAM-13 } & 21.52 & 14.94 & 2.47 & 5.56 & 10.83 \\
\hline $\mathbf{T}_{14}$ & \multicolumn{2}{|c|}{ GKTAM-14 } & 23.58 & 16.73 & 2.44 & 5.78 & 11.41 \\
\hline $\mathbf{T}_{15}$ & \multicolumn{2}{|c|}{ GKTAM-15 } & 21.10 & 14.36 & 2.35 & 5.86 & 10.41 \\
\hline $\mathbf{T}_{16}$ & \multicolumn{2}{|c|}{ GKTAM-16 } & 20.82 & 12.94 & 2.52 & 5.63 & 10.15 \\
\hline $\mathbf{T}_{17}$ & \multicolumn{2}{|c|}{ GKTAM-17 } & 19.17 & 15.82 & 2.35 & 5.27 & 9.90 \\
\hline $\mathbf{T}_{18}$ & \multicolumn{2}{|c|}{ GKTAM-18 } & 35.61 & 19.85 & 3.60 & 10.30 & 18.94 \\
\hline $\mathbf{T}_{19}$ & \multicolumn{2}{|c|}{ GKTAM-19 } & 31.08 & 17.76 & 2.85 & 7.88 & 16.16 \\
\hline $\mathbf{T}_{20}$ & \multicolumn{2}{|c|}{ GKTAM-20 } & 18.89 & 14.69 & 2.34 & 5.51 & 9.30 \\
\hline $\mathbf{T}_{21}$ & \multicolumn{2}{|c|}{ GKTAM-21 } & 19.41 & 15.76 & 2.35 & 5.79 & 9.10 \\
\hline \multirow[t]{7}{*}{$\mathbf{T}_{22}$} & \multicolumn{2}{|c|}{ GKTAM-22 } & 19.29 & 16.06 & 2.42 & 5.03 & 9.44 \\
\hline & \multicolumn{2}{|c|}{ Mean } & 24.27 & 15.65 & 2.53 & 6.31 & 11.92 \\
\hline & \multirow[t]{2}{*}{ Range } & Maximum & 35.61 & 19.85 & 3.60 & 10.30 & 18.94 \\
\hline & & Minimum & 18.89 & 12.12 & 2.18 & 5.03 & 9.10 \\
\hline & \multicolumn{2}{|c|}{$F$ test $(\mathrm{p} \leq 0.05)$} & $*$ & $*$ & $*$ & $*$ & $*$ \\
\hline & \multicolumn{2}{|c|}{ S.Em \pm} & 0.78 & 0.62 & 0.13 & 0.30 & 0.44 \\
\hline & \multicolumn{2}{|c|}{ C.D at $5 \%$} & 2.23 & 1.77 & 0.38 & 0.85 & 1.26 \\
\hline
\end{tabular}


Table.2 Variability exhibited for Shell weight per fruit, Pulp per cent, shell per cent, seed per cent and fiber per cent by different tamarind genotypes

\begin{tabular}{|c|c|c|c|c|c|c|c|}
\hline Treatments & \multicolumn{2}{|c|}{ Genotypes } & $\begin{array}{l}\text { Shell weight per } \\
\text { fruit (g) }\end{array}$ & $\begin{array}{c}\text { Pulp per } \\
\text { cent }\end{array}$ & $\begin{array}{c}\text { Shell per } \\
\text { cent }\end{array}$ & $\begin{array}{c}\text { Seed per } \\
\text { cent }\end{array}$ & $\begin{array}{c}\text { Fiber } \\
\text { per cent }\end{array}$ \\
\hline $\mathbf{T}_{1}$ & \multicolumn{2}{|c|}{ GKTAM-1 } & 6.80 & 55.79 & 20.44 & 25.09 & 4.25 \\
\hline $\mathbf{T}_{2}$ & \multicolumn{2}{|c|}{ GKTAM-2 } & 5.21 & 49.14 & 18.99 & 24.38 & 4.17 \\
\hline $\mathbf{T}_{3}$ & \multicolumn{2}{|c|}{ GKTAM-3 } & 5.03 & 48.24 & 18.30 & 23.02 & 4.02 \\
\hline $\mathbf{T}_{4}$ & \multicolumn{2}{|c|}{ GKTAM-4 } & 4.80 & 47.32 & 19.31 & 23.42 & 4.34 \\
\hline $\mathbf{T}_{5}$ & \multicolumn{2}{|c|}{ GKTAM-5 } & 5.83 & 47.65 & 21.93 & 22.31 & 4.29 \\
\hline $\mathbf{T}_{6}$ & \multicolumn{2}{|c|}{ GKTAM-6 } & 4.50 & 52.61 & 21.16 & 26.24 & 5.04 \\
\hline $\mathbf{T}_{7}$ & \multicolumn{2}{|c|}{ GKTAM-7 } & 5.36 & 43.64 & 20.52 & 24.60 & 4.64 \\
\hline $\mathbf{T}_{8}$ & \multicolumn{2}{|c|}{ GKTAM-8 } & 4.59 & 49.26 & 22.49 & 26.91 & 5.27 \\
\hline $\mathbf{T}_{9}$ & \multicolumn{2}{|c|}{ GKTAM-9 } & 5.38 & 44.51 & 19.30 & 26.79 & 4.61 \\
\hline$T_{10}$ & \multicolumn{2}{|c|}{ GKTAM-10 } & 4.19 & 47.35 & 18.46 & 26.00 & 3.71 \\
\hline$T_{11}$ & \multicolumn{2}{|c|}{ GKTAM-11 } & 4.30 & 50.41 & 20.67 & 27.66 & 4.82 \\
\hline $\mathbf{T}_{12}$ & \multicolumn{2}{|c|}{ GKTAM-12 } & 4.81 & 43.25 & 19.76 & 27.35 & 4.99 \\
\hline $\mathbf{T}_{13}$ & \multicolumn{2}{|c|}{ GKTAM-13 } & 4.20 & 50.37 & 19.54 & 25.98 & 4.28 \\
\hline $\mathbf{T}_{14}$ & \multicolumn{2}{|c|}{ GKTAM-14 } & 4.68 & 48.44 & 19.87 & 24.60 & 4.34 \\
\hline $\mathbf{T}_{15}$ & \multicolumn{2}{|c|}{ GKTAM-15 } & 4.13 & 49.34 & 19.58 & 27.85 & 4.58 \\
\hline $\mathbf{T}_{16}$ & \multicolumn{2}{|c|}{ GKTAM-16 } & 4.38 & 48.79 & 21.04 & 27.20 & 4.43 \\
\hline $\mathbf{T}_{17}$ & \multicolumn{2}{|c|}{ GKTAM-17 } & 3.89 & 51.64 & 20.31 & 27.57 & 4.86 \\
\hline $\mathbf{T}_{18}$ & \multicolumn{2}{|c|}{ GKTAM-18 } & 8.73 & 53.24 & 24.51 & 28.99 & 6.65 \\
\hline$T_{19}$ & \multicolumn{2}{|c|}{ GKTAM-19 } & 5.53 & 52.09 & 17.90 & 25.60 & 4.00 \\
\hline $\mathbf{T}_{20}$ & \multicolumn{2}{|c|}{ GKTAM-20 } & 4.30 & 49.25 & 22.76 & 26.86 & 4.15 \\
\hline $\mathbf{T}_{21}$ & \multicolumn{2}{|c|}{ GKTAM-21 } & 4.40 & 46.98 & 22.69 & 27.54 & 4.80 \\
\hline $\mathbf{T}_{22}$ & \multicolumn{2}{|c|}{ GKTAM-22 } & 4.23 & 49.06 & 21.98 & 25.99 & 4.77 \\
\hline & \multicolumn{2}{|c|}{ Mean } & 4.97 & 49.02 & 20.52 & 26.14 & 4.59 \\
\hline & \multirow[t]{2}{*}{ Range } & Maximum & 8.73 & 53.24 & 24.51 & 28.99 & 6.65 \\
\hline & & Minimum & 3.89 & 43.25 & 17.90 & 25.60 & 3.71 \\
\hline & \multicolumn{2}{|c|}{$\mathrm{F}$ test $(\mathrm{p} \leq 0.05)$} & $*$ & $*$ & $*$ & $*$ & $*$ \\
\hline & \multicolumn{2}{|c|}{ S.Em \pm} & 0.18 & 1.78 & 0.73 & 0.85 & 0.25 \\
\hline & \multicolumn{2}{|c|}{ C.D at $5 \%$} & 0.51 & 5.09 & 2.08 & 2.43 & 0.72 \\
\hline
\end{tabular}


Table.3 Qualitative parameters of the pulp in tamarind genotypes

\begin{tabular}{|c|c|c|c|c|c|}
\hline Treatments & \multicolumn{2}{|c|}{ Genotypes } & Acidity (\%) & Total soluble solids, $\left({ }^{\circ}\right.$ Brix $)$ & pH \\
\hline $\mathbf{T}_{1}$ & \multicolumn{2}{|c|}{ GKTAM-1 } & 14.29 & 17.70 & 2.56 \\
\hline $\mathbf{T}_{2}$ & \multicolumn{2}{|c|}{ GKTAM-2 } & 09.67 & 12.14 & 2.72 \\
\hline $\mathbf{T}_{3}$ & \multicolumn{2}{|c|}{ GKTAM-3 } & 08.48 & 15.57 & 3.09 \\
\hline $\mathbf{T}_{4}$ & \multicolumn{2}{|c|}{ GKTAM-4 } & 12.24 & 13.95 & 2.85 \\
\hline $\mathbf{T}_{5}$ & \multicolumn{2}{|c|}{ GKTAM-5 } & 10.50 & 14.37 & 2.91 \\
\hline $\mathbf{T}_{6}$ & \multicolumn{2}{|c|}{ GKTAM-6 } & 11.31 & 15.85 & 3.11 \\
\hline $\mathbf{T}_{7}$ & \multicolumn{2}{|c|}{ GKTAM-7 } & 10.51 & 16.42 & 2.98 \\
\hline $\mathbf{T}_{8}$ & \multicolumn{2}{|c|}{ GKTAM-8 } & 11.37 & 15.42 & 2.76 \\
\hline $\mathbf{T}_{9}$ & \multicolumn{2}{|c|}{ GKTAM-9 } & 13.08 & 19.19 & 3.32 \\
\hline$T_{10}$ & \multicolumn{2}{|c|}{ GKTAM-10 } & 13.30 & 18.14 & 3.52 \\
\hline$T_{11}$ & \multicolumn{2}{|c|}{ GKTAM-11 } & 11.73 & 16.10 & 2.54 \\
\hline $\mathbf{T}_{12}$ & \multicolumn{2}{|c|}{ GKTAM-12 } & 09.68 & 15.98 & 2.64 \\
\hline $\mathbf{T}_{13}$ & \multicolumn{2}{|c|}{ GKTAM-13 } & 08.62 & 16.15 & 2.79 \\
\hline $\mathbf{T}_{14}$ & \multicolumn{2}{|c|}{ GKTAM-14 } & 08.57 & 16.96 & 2.75 \\
\hline $\mathbf{T}_{15}$ & \multicolumn{2}{|c|}{ GKTAM-15 } & 09.74 & 14.69 & 3.14 \\
\hline $\mathbf{T}_{16}$ & \multicolumn{2}{|c|}{ GKTAM-16 } & 08.63 & 21.37 & 2.99 \\
\hline $\mathbf{T}_{17}$ & \multicolumn{2}{|c|}{ GKTAM-17 } & 08.25 & 16.90 & 2.78 \\
\hline $\mathbf{T}_{18}$ & \multicolumn{2}{|c|}{ GKTAM-18 } & 13.41 & 18.76 & 2.64 \\
\hline$T_{19}$ & \multicolumn{2}{|c|}{ GKTAM-19 } & 16.89 & 16.32 & 3.27 \\
\hline $\mathbf{T}_{20}$ & \multicolumn{2}{|c|}{ GKTAM-20 } & 09.00 & 13.67 & 3.18 \\
\hline$T_{21}$ & \multicolumn{2}{|c|}{ GKTAM-21 } & 10.26 & 14.42 & 2.82 \\
\hline \multirow[t]{7}{*}{$\mathbf{T}_{22}$} & GK & M-22 & 11.51 & 14.71 & 3.14 \\
\hline & \multicolumn{2}{|c|}{ Mean } & 10.96 & 16.13 & 2.93 \\
\hline & \multirow[t]{2}{*}{ Range } & Maximum & 16.89 & 21.37 & 3.52 \\
\hline & & Minimum & 08.25 & 12.14 & 2.54 \\
\hline & \multicolumn{2}{|c|}{$F$ test $(p \leq 0.05)$} & $*$ & $*$ & $*$ \\
\hline & \multicolumn{2}{|c|}{ S.Em \pm} & 0.21 & 0.28 & 0.06 \\
\hline & \multicolumn{2}{|c|}{ C.D at $5 \%$} & 0.61 & 0.79 & 0.17 \\
\hline
\end{tabular}

The lowest pulp per cent was observed in GKTAM-7 of 43.64 per cent. Maximum shell per cent was recorded in GKTAM -18 of 24.51 per cent, followed by GKVK-21 (22.69 per cent). The minimum shell (\%) was recorded in GKTAM -17 of 17.90 per cent. Similar trend was followed in seed per cent also. The higher seed per cent was recorded in GKVK-18 of 28.99 per cent, which was on par with GKTAM-11 of 27.66 per cent. Lower seed per cent was recorded GKTAM-5 of 22.31 per cent. Same trend was followed in fiber per cent also, the higher fiber per cent was recorded in GKTAM-18 of 6.65 per cent, which was on par with GKTAM -8 of 5.27 per cent. Lower fiber per cent was recorded GKTAM-7 of 3.71 per cent.

The variations in the pulp, seed, shell, and vein per cent was due to their genotypic differences Shivanandam (1980) and Hanamashetti (1996). The difference in shell weight can be clearly attributed to the difference in size of the fruit. The difference 
in fibre weight among the genotypes may be due to the differences in the rate of development of vascular tissue in fruits was earlier reported by Hanamashetti (1997). The difference in seed weight may be attributed to the difference in the number and size of seeds. The difference in seed number may be attributed to the difference in length of pod and ovule fertility as opined by Hanamashetti, (1996).

The genotypes differed significantly with respect to acidity, total soluble solids and $\mathrm{pH}$ content (Table 3 ). The highest acidity was recorded in GKTAM-19 (16.89\%) and the least was recorded in GKTAM-17 (8.25\%). TSS was recorded in GKTAM-19 (21.37 oBrix) while the minimum was recorded in GKTAM-2 (12.14 ${ }^{\circ}$ Brix). The highest $\mathrm{pH}$ of the pulp was recorded in GKTAM-19 (3.52) and the lowest $\mathrm{pH}$ was recorded in GKTAM$11(2.54)$.

These variation in acidity is due to the difference in sugar content of the pulp and also inherent genetic makeup of each genotype, difference in total soluble solids content is due to the difference in sugar content of the pulp and $\mathrm{pH}$ in the concentrate these are attributed to the difference in acid to sugar ratio of the pulp and also a distinct feature of the different genotypes. The similar outcome with respect to the above characters were earlier reported by Patil (2004), Prabhushankar et al., (2004), El-Siddig et al., (2006), Divakara (2009), Adeola and Aworh (2012), Joshi et al., (2013) and Sharma et al., (2015).

In conclusions among the 22 tamarind genotypes evaluated, GKTAM-18 showed maximum pod weight $(35.61 \mathrm{~g})$, pod length $(19.85 \mathrm{~cm})$, pod width $(3.60 \mathrm{~cm})$, pulp weight $(18.94 \mathrm{~g})$, shell weight $(8.73 \mathrm{~g})$, seed per cent (28.99\%), fiber per cent $(6.65 \%)$ content and acidity per cent $(18.94 \%)$ another tamarind genotype GKTAM-1recorded maximum pulp per cent (55.79\%), higher TSS was observed in GKTAM-16 (21.37 ${ }^{\circ}$ Brix) From the conclusion of the present study revealed that GKTAM-18 showed the highest mean performance of morphometric traits and phytochemical characters and it can be used for further evaluation programme for commercial cultivation through vegetative propagation.

\section{References}

Adeola, A. A. and Aworh, C. O., 2012, Development and sensory evaluation of an improved beverage from Nigeria's tamarind fruit. African $J$. Food Agric. Nutr. Development, 10 (9): 4079-4092.

Divakara, B. N., 2008, Variation and character association for various pod traits in Tamarindus indica L. Indian Forester, 134(5): 687-696.

Divakara, B. N., 2009, Variation and character association for various pulp biochemical traits in Tamarindus indica L. Indian Forester, 135(1): 99110.

El-Siddig, K., Gunesana, H. P. M., Prasad, B. A., Pushpukumara, D. K. N. G., Ramana, K. V. R., Vijayananand, P. and Williams, J. T., 2006, Fruits for the future Tamarind (Tamarindus indica L.) (Revised). Southampton Centre for Underutilized Crops, Southampton, UK. pp. 9-12.

Fandohan, B., Assogbadjo, A. E., Kakai, R. G. and Kyndt, T., 2011, Quantitative morphological descriptors confirm traditionally classified morphotypes of Tamarindus indica L. Fruits. Genet.Resour. Crop Evol., 58: 299309.

Hanamashetti, S. I., 1996, Vegetative propagation and genetic diversity evaluation in Tamarind. Ph.D. (Hort.) 
Thesis, UAS, Dharwad. Karnataka.

Hanamashetti, S. I., 1997, Evaluation of promising genotypes of tamarind, Tamarindus indica L. Proc. National Symposium on Tamarindus indica L., Tirupati, Andhra Pradesh, India. pp. 59-68.

Joshi, A. A., Kshirsagar, R. B. and Chilkawar, P., 2013, Comparative evaluation of physico-chemical characteristics of three different varieties of tamarind (Ajanta, Thailand and Local). Int. J. Curr. Res., 5(8): 2140-2142.

Patil, S. S., 2004, Genetics and propagation studies in tamarind (Tamarindus indica
L.). Ph.D (Hort) Thesis, Univ. Agric. Sci., Dharwad (India).

Ranganna, S., 1979, Manual of analysis of fruits and vegetable products. Tata McGraw-Hill Publishing Co. Ltd. New Delhi. pp. 1-20.

Rao, K. D. and Subramanyam, K., 2010, Varietal evaluation of tamarind under scarce rainfall zone.Agric. Sci. Digest., 30(1): 42-45.

Sharma, D. K., Alkade, S. A. and Virdia, H. M., 2015, Genetic variability in tamarind Tamarindus indica L. in South Gujarat.Curr.Horti.,3(2): 43-46.

\section{How to cite this article:}

Praveenakumar, R., G. Gopinath, S. Shyamalamma' S. Ramesh, M. Vasundhara and Chandre Gowda, M. 2020. Characterization of Tamarind Accessions for Morphometric Traits and Phytochemical Composition. Int.J.Curr.Microbiol.App.Sci. 9(10): 1183-1189.

doi: https://doi.org/10.20546/ijcmas.2020.910.142 